\title{
“Tripe Soup for All Women!” \\ Transgression of Gender Boundaries \\ as Part of Female Identity in Communist \\ and Contemporary Bulgaria
}

\section{Albena Shkodrova}

Institut für soziale Bewegung, Ruhr-Universität Bochum

Raised during the last two decades of communist Bulgaria, ${ }^{1}$ I have no recollections of when I first tried tripe soup. It has always been around: spicy, steaming and pungent. Shkembe chorba was never cooked at home, but it seemed ubiquitous, offered at unpretentious (even by communist standards) specialized joints. These were places with reduced visibility: cigarette smoke and steam from the cauldrons would hang in a thick fog on cold days. There was also a cloud of sound hovering over them: music playing from a radio on the wall and chairs being dragged across the cement floor made the background noise so loud that people had to communicate by shouting.

Since my teenage years, once in a while I would end up there - I loved the soup, and these visits made me feel like an adult. I associated tripe soup with specific social groups: weird and colourful personalities, workers and drunkards, bohemians and pariahs. But it never occurred to me that it had anything to do with gender. At least not until many years later, in 2014, when I encountered a Bulgarian web post: “The wife's castle, built of salads, stews and other halffoods, has been destroyed. Clouds of garlic aromas announce a heavy adultery from the entrance hall. Her mother never told her that in the men's world there is one great masterpiece. And it can only be cooked by other men. Tripe soup. (...) This 'soup', so repulsive to you, is the love of his life. And your Waterloo."2

So wrote the author Nikolay Ilchevski. ${ }^{3}$ Nonchalantly dismissing what I saw as my birth right to enjoy garlicky tripe soup, this little article turned out to be

\footnotetext{
1 An early version of this article was presented at the Dublin Gastronomy Symposium in 2018.

2 All translations of quotations from the Bulgarian are by the author.

3 ILCHEVSKI, Nikolay: Iznevyara na petia etazh: Gradski razkazi [Adultery on the Fifth Floor: Urban Stories]. Plovdiv, Book-Rix 2014, p. 49. First read as a web-publication on htttp://www. bgnow.eu.
} 
part of a whole stream of publications suggesting that tripe soup is constructed as a gendered food. It raised the question of what had shifted in Bulgarian society, in the economy, in its culture - what structural forces had reshaped the construct, or was I perhaps so unaware of the gender boundaries around me?

\section{Gendered Food}

All societies tend to gender food, i. e. divide it in "masculine" and "feminine", as a growing body of research in cultural, historical, behavioural, marketing and food studies has established lately. ${ }^{4}$ In investigating how cultural frameworks entangle dishes and ingredients in complex sets of associations with the sexes and charge them with related meanings, scientists have established that gender "stereotypes" are among the most consistently observed stereotypes related to food. ${ }^{5}$ They exist in every cultural framework yet display some specific variations across cultures and historical periods. ${ }^{6}$ They are used to signal identity and manage the impression which individuals make on others. ${ }^{7}$ In this regard, scientists concur

4 BASFIRINCI, Cigdem - CILINGIR, Zuhal: Gender-Based Food Stereotypes among Turkish University Students. In: Young Consumers, Vol. 18, No. 3 (2017), pp. 223-244; CAVAZZA, Nicoletta - GUIDETTI, Margherita - BUTERA, Fabrizio: Ingredients of Gender-Based Stereotypes about Food: Indirect Influence of Food Type, Portion Size and Presentation on Gendered Intentions to Eat. In: Appetite, Vol. 91 (2015), pp. 266-272; McPHAIL, Deborah - BEAGAN, Brenda - CHAPMAN, Gwen E.: "I Don't Want to be Sexist but..." Denying and Re-Inscribing Gender Through Food. In: Food, Culture \& Society, Vol. 15, No. 3 (2012), pp. 473-489; LUPTON, Deborah: Food, the Body, and the Self. London - Thousand Oaks (CA), Sage Publications 1996; HIRSCHMAN, Elizabeth C. - CARSCADDEN, Nicole - FLEISCHAUER, Lindsay: Exploring the Architecture of Contemporary American Foodways. In: Advances in Consumer Research [online], Vol. 31 (2004), pp. 548-553. [Accessed 2021-11-25.] Available from: https:// www.acrwebsite.org/volumes/8962/volumes/v31/NA-31.

5 KIMURA, Atsushi - WADA, Yuji - GOTO, Sho-ichi et al.: Implicit Gender-Based Food Stereotypes: Semantic Priming Experiments on Young Japanese. In: Appetite, Vol. 52, No. 2 (2009), pp. 521-524.

${ }^{6}$ EKEBAS-TUREDI, Ceren - CILINGIR, Zuhal - BASFIRINCI, Cigdem - PINAR, Musa: A CrossCultural Analysis of Gender-Based Food Stereotypes and Consumption Intentions among Millennial Consumers. In: Journal of International Consumer Marketing, Vol. 33, No. 2 (2021), pp. 209-225; COUNIHAN, Carole M. - KAPLAN, Steven L.: Food and Gender: Identity and Power. London, Routledge 1998; SOBAL, Jeffery: Men, Meat, and Marriage: Models of Masculinity. In: Food and Foodways, Vol. 13, No. 1-2 (2005), pp. 135-158.

7 EKEBAS-TUREDI, C. et al: A Cross-Cultural Analysis of Gender-Based Food Stereotypes; VARTANIAN, Lenny R. - HERMAN, C. Peter - POLIVY, Janet: Consumption Stereotypes and Impression Management: How You Are What You Eat. In: Appetite, Vol. 48, No. 3 (2007), pp. 265-277. 
that gender influences the individual's food preferences and consumption patterns. ${ }^{8}$ It seems less easy to determine the nature and limits of this influence.

One line of research explores the "gender" of particular foods and its consistency across cultural borders. By far the most prominent examples have proven to be the links between meat and masculinity ${ }^{9}$ and meat and alcohol. ${ }^{10}$ Femininity, on the other hand, seems to be more often associated with the consumption of fruit, salad, sweets and food that is considered to be healthy. ${ }^{11}$ Investigating the effect of cultural differences on these widespread perceptions, Ceren EkebasTuredi et al. established that there is significant overlap across cultures. ${ }^{12}$ However, they also found differences: for example, deli wraps, bread, fish and soups were revealed to be "female" foods in the United States but "male" ones in Turkey.

The research thus far argues that food consumption is used to manifest gender identity, particularly under circumstances which make gender salient. ${ }^{13}$ But many discussions of food gendering have left some key underlying questions

${ }^{8}$ COUNIHAN, C. M. - KAPLAN, S. L.: Food and Gender; O'DOHERTY JENSEN, Katherine HOLM, Lotte: Preferences, Quantities and Concerns: Socio-Cultural Perspectives on the Gendered Consumption of Foods. In: European Journal of Clinical Nutrition, Vol. 53, No. 5 (1999), pp. 351-359; MOONEY, Kim M. - LORENZ, Erica: The Effects of Food and Gender on Interpersonal Perceptions. In: Sex Roles, Vol. 36, No. 9 (1997), p. 639-653.

9 BOURDIEU, Pierre: Distinction: A Social Critique of the Judgement of Taste. Cambridge (Mass.), Harvard University Press 1984; HERMAN, C. Peter - POLIVY, Janet: Sex and Gender Differences in Eating Behavior. In: CHRISLER, Joan C. - McCREARY, Donald R. (eds.): Handbook of Gender Research in Psychology, Vol. 1: Gender Research in General and Experimental Psychology. New York, Springer 2010, pp. 455-469; McPHAIL, D. - BEAGAN, B. - CHAPMAN, G. E.: "I Don't Want to be Sexist But..."; TWIGG, Julia: Vegetarianism and the Meanings of Meat. In: MURCOTT, A. (ed.): The Sociology of Food and Eating: Essays on the Sociological Significance of Food. Aldershot, Gower 1983, pp. 18-30; ADAMS, Carol J.: Sexual Politics of Meat: A Feminist-Vegetarian Critical Theory $-20^{\text {th }}$ anniversary. New York, Continuum 2010 [1 ${ }^{\text {st }}$ edition 1990].

${ }^{10}$ O'DOHERTY JENSEN, K. - HOLM, L.: Preferences, Quantities and Concerns.

${ }^{11}$ MOONEY, K. M. - LORENZ, E.: The Effects of Food and Gender on Interpersonal Perceptions; VARTANIAN, L. R. - HERMAN, C. P. - POLIVY, J.: Consumption Stereotypes and Impression Management; O'DOHERTY JENSEN, K. - HOLM, L.: Preferences, Quantities and Concerns.

${ }^{12}$ EKEBAS-TUREDI, C. et al.: A Cross-Cultural Analysis of Gender-Based Food Stereotypes.

${ }^{13}$ BASOW, Susan A. - KOBRYNOWICZ, Diane: What Is She Eating? The Effects of Meal Size on Impressions of a Female Eater. In: Sex Roles, Vol. 28, No. 5 (1993), pp. 335-344; CONNER, Mark - ARMITAGE, Christopher J.: The Social Psychology of Food. Buckingham, Open University Press 2002; CAMPOS, Lúcia - BERNARDES, Sónia - GODINHO, Cristina: Food as a Way to Convey Masculinities: How Conformity to Hegemonic Masculinity Norms Influences Men's and Women's Food Consumption. In: Journal of Health Psychology, Vol. 25, No. 12 (2020), pp. 1842-1856. 
unaddressed, such as how to understand the widespread association of certain traits with either sex in the first place. Critical of the dominance of socio-cultural explanations, the American psychologist Alice H. Eagly argued that stereotypical perceptions of the personal traits of the sexes most likely reflect actual differences in the distribution of characteristics among women and men. She even suggested that the public estimations of these differences could be deemed accurate, and there is no convincing evidence that gender stereotypes exaggerate reality. ${ }^{14}$ It could be added that neither is there any evidence that the associations of certain traits with a specific sex, which seem consistent across countries, ${ }^{15}$ can be reversed. The single exception seems to have been the long-discredited research of Margaret Mead on Samoa and New Guinea. ${ }^{16}$

Revealing how the dramatic change of gender roles in the United States between 1974 and 1991 failed to affect the stereotypical perceptions of both sexes' personal traits, Lloyd B. Lueptow et al. noted that "certain innate differences between the sexes" probably influence these perceptions "to some undetermined degree" ${ }^{17}$ Current research reveals an overwhelming consistency of perceptions as to what constitutes the "female" and the "male". If the association of "maleness" with traits like power or dominance and "femaleness" with sensitiveness or empathy, which is persistent across cultures and historical periods, is not "fixed" or related to what is "innate" to either of the sexes, then this layer of codification is at least a universally conservative one and difficult to change.

As a somewhat crude generalization, the current research discusses elements of what seems to be various levels of codification, without making a distinction between them or considering their interaction. For example, the research mentioned above that found that certain foods (soup, fish, deli wraps) are "female" in one culture and "male" in another sought an explanation in the different contexts within which these foods are sold and consumed in the two countries.

\footnotetext{
${ }^{14}$ EAGLY, Alice H.: The Science and Politics of Comparing Women and Men. In: American Psychologist, Vol. 50, No. 3 (1995), pp. 145-158.

${ }^{15}$ WILLIAMS, John E. - BEST, Deborah L.: Measuring Sex Stereotypes: A Thirty-Nation Study. Beverly Hills (CA), Sage 1982.

${ }^{16}$ MEAD, Margaret: Coming of Age in Samoa. New York, William Morrow \& Co. 1928; IDEM: Growing up in New Guinea. Garden City, Blue Ribbon Books 1930; LUEPTOW, Lloyd B. - GAROVICH, Lori - LUEPTOW, Margaret B.: The Persistence of Gender Stereotypes in the Face of Changing Sex Roles: Evidence Contrary to the Sociocultural Model. In: Ethology and Sociobiology, Vol. 16, No. 6 (1995), pp. 509-530; BROWN, D. E.: Human Universals. Philadelphia, Temple University Press 1991; DALY, Martin - WILSON, Margot: Homicide. New York, Aldine de Gruyter 1988.

${ }^{17}$ LUEPTOW, L. B - GAROVICH, L. - LUEPTOW, M. B.: The Persistence of Gender Stereotypes in the Face of Changing Sex Roles, p. 526.
} 
The observed variation was explained by the changing qualities associated with particular foods, not with different ideas about which personal traits are considered feminine or masculine. Yet the distinction between these two levels was not articulated. Similar limitations are shown by the investigations of the association of hummus or espresso with masculinity. ${ }^{18}$

This article suggests and applies a conceptualization of the food gendering process that is composed of (at least) three levels of codification: (1) what constitutes feminine or masculine in the particular framework; (2) what qualities are assigned to a particular food and how they relate to gender; and (3) how representatives of the different genders negotiate their attitudes to a particular dish in terms of their gender identity. Considering the fluctuations or lack thereof in each of these, as well as their possible interaction with one another, provides a more nuanced understanding of the social processes forming stereotypes/popular perceptions. Acknowledging that stereotypes are by default "fuzzy categories organized around prototypes", 19 the research investigates their structure and fluctuation.

This article presents a case study of perceptions in communist and post-communist Bulgaria about tripe soup - a dish inherited from the urban culture of the Ottoman Empire with a great potential to be perceived as manly. The research investigates how its "gendering" has been constructed, fluctuated and challenged.

Bulgaria presents an interesting case study since after the Second World War its patriarchal and predominantly rural society was subjected to radical social engineering under the Soviet-dominated communist rule in Eastern Europe. To a certain degree, the gender-related discussions and processes in society could be considered representative for all of the Eastern bloc in this period. Yet the Ottoman influences and the relatively late industrialization and urbanisation provide for distinctive layers of differences. The article focuses on the communist and the post-communist period since they were particularly dynamic in regard to gender perceptions, while they are also abundantly documented and the sources are better suited for this research.

\footnotetext{
${ }^{18}$ HIRSCH, Dafna: Hummus Masculinity in Israel. In: Food, Culture \& Society, Vol. 19, No. 2 (2016), pp. 337-359; REITZ, Julie Kjendal: Espresso: A Shot of Masculinity. In: Ibid., Vol. 10, No. 1 (2007), p. 7-21.

${ }^{19}$ HELGESON, Vicki: Prototypes of Masculinity and Femininity. In: Sex Roles, Vol. 31, No. 11-12 (1994), pp. 653-682.
} 
Sources and Methodology

The research makes use of several sets of historical sources specific to the different periods. To achieve a better contextualization, pre-communist discourses and the structural aspects of tripe soup consumption are briefly outlined on the basis of well-known autobiographical and ethnographic writings on Bulgarian everyday life. ${ }^{20}$ While only containing grains of relevant information, these sources deliver insights into actual perceptions and practices. They were supplemented with another, more consistent, but an often more ideological source: ${ }^{21}$ a selection of 37 cookbooks from the period between 1870 and 1989. These include all 11 of the most relevant cookbooks for the period until 1909 as well as 13 cookbooks each for the periods 1909-1948 and 1948-1989. ${ }^{22}$ This selection was made on the basis of several criteria: the cookbooks had to be Bulgarian in origin, had to include meat recipes, had to have their first publication dates evenly spread out throughout the studied period and had to cover the entire spectrum of readership: rural and urban, professional and domestic, higher and lower budget households (in the pre-communist period).

Due to the explosion of cookery literature after 1989, a similar selection became problematic; and, as the available sources on individual perspectives are abundant, a different set of sources was used for the post-communist period. Post-communist (and communist, in part) perspectives on tripe soup and actual consumption practices were researched on the basis of individual accounts from a large body of writing in Bulgarian available on the Internet. Among the 100 most popular search results with the key word шкембе чорба (tripe soup), some 30 proved to be relevant by discussing the status of the dish within a specific context. They vary from (relatively popular) personal blogs to national media (such

${ }^{20}$ KARAVELOV, Lyuben: Mamino detentse [Mama's child]. Sofia, Bulgarski pisatel 1973 [1 $1^{\text {st }}$ edition 1877]; STOYANOV, Zahari: Zapiski po bulgarskite vustania [Notes of the Bulgarian Uprisings]. Sofia, Bulgarski pisatel 1987 [1 $1^{\text {st }}$ edition 1884-1892]; KOSTENTSEVA, Rayna: Moyat roden grad Sofia [My Native Sofia]. Sofia, Riva 2008 [1 $1^{\text {st }}$ edition 1979]; ALVADZHIEV, Nikola: Plovdivska hronika 1900-1912 [Plovdiv Chronicles, 1900-1912]. Plovdiv, Hristo G. Danov 1971; KANAZIRSKI-VERIN, Georgi: Sofia predi 50 godini [Sofia 50 years ago]. Sofia, Bulgarska kniga 1947; GEORGIEV, Georgi: Sofia i sofiantsi [Sofia and Sofianites]. Sofia, Nauka i izkustvo 1982; TENEV, Dragan: Trista-hilyadna Sofia i az mezhdu voynite [Three-hundred-thousand Sofia and me between the Wars]. Sofia, Laska 1992; VEZHINOV, Pavel: Izbrani suchinenia $v 4$ toma [Selected writings in four volumes], Vol. 3. Sofia, Bulgarski pisatel 1977.

${ }^{21}$ ALBALA, Ken: Cookbooks as Historical Documents. In: PILCHER, Jeffrey M. (ed.): The Oxford Handbook of Food History. Oxford - New York, Oxford University Press 2012; NOTAKER, Henry: Printed Cookbooks: Food History, Book History, and Literature. In: Food and History, Vol. 10, No. 2 (2012), pp. 131-159.

22 For complete cookbooks bibliography (chronologically listed), see the Appendix. 
as bTV, e-vesting, Peak and Blitz.bg) and the personal sites of chefs (Ivan Zvezdev), journalists and writers (Hristo Kyosev, Milena Fuchedzhieva and Nikolay Ilchevski). ${ }^{23}$ The results that have been dated were mostly posted between 2012 and 2017.

The sources were subjected to a hermeneutic interpretation - they were considered in their context and as being revealing of individual perceptions and socially constructed meanings and understandings. Particular attention was paid to the symbolic codes, which transpired from the various texts and revealed sets of associations - patterns were sought in them and used in the construction of the arguments below. The retrospective character of some of the accounts was taken into consideration and discussed, and so was the ideological character of cookbooks as historical sources - particularly those published by the monopolized state publishers under communism.

The article has three main parts. The first outlines the history of tripe soup in Bulgaria with particular attention to its ingredients, the preparation method and consumption, which render it suitable for "gendering". The second part focuses on several key aspects that appear in popular discourses on tripe soup. The third part presents and analyses the patterns of gendering this dish throughout each period, including attempts to challenge the construction of tripe soup as a masculine food.

The History of Tripe Soup in Bulgaria ${ }^{24}$

Prior to the development of modern Bulgarian urban culture by the end of the nineteenth century, there is no evidence that tripe was used for human consumption in the country. Any clues to the contrary are inconclusive. One of the most important chroniclers of mid-nineteenth century Bulgaria, Zahari Stoyanov, described the practice among poor people to hang animals' stomachs on their windows as an alternative to unaffordable glass panes. ${ }^{25}$ According to a later, autobiographical account by fiction writer Pavel Vezhinov, cattle intestines and stomachs were nonchalantly discarded into gutters by butchers in the countryside. Even so, they did not always go to waste: "We only had to find and catch them in time in the dirty, reeking water. We did that with iron hooks or just with

\footnotetext{
${ }^{23}$ Full references are listed further in the text, where the writings are discussed.

${ }^{24}$ Some parts of this section of the article have been published in the chapter "Tripe Treats" in SHKODROVA, Albena: Communist Gourmet: The Curious Story of Food in the People's Republic Bulgaria. Budapest - Vienna - New York, CEU Press 2021.

${ }^{25}$ STOYANOV, Zahari: Zapiski po bulgarskite vustania, Vol. 2, p. 214.
} 
our hands." ${ }^{26}$ Vezhinov recalled of the 1920s that some of his playmates would take their catch home by the bucketful, where their mothers would boil and mince it. He hesitated however, as to whether it was used for human consumption: “They didn't eat it, of course, although I am not sure about that," he wrote. But it was certainly fed to the hens. "Never again did I see so strong and wellfed hens as those from my neighbourhood. Rancorous from the food, the local cocks grew belligerent," the writer remarked in this account. ${ }^{27}$

The history of tripe consumption in Bulgaria becomes only slightly more tangible in 1870 with the publication of the first Bulgarian cookbook. The writer, prominent poet, ethnographer and politician Petko Slaveykov spent years in Constantinople editing a Bulgarian edition of the Bible. He published a collection of recipes titled Cookbook, or Advice on Dishes of All Sorts, as They Are Prepared in Tsarigrad [the old Bulgarian name for Constantinople]. ${ }^{28}$ His book contained a recipe for tripe, but not for tripe soup.

Further insights are offered by another nineteenth-century Bulgarian writer, Lyuben Karavelov. Ridiculing the hedonism of his Bulgarian contemporaries, he listed important landmarks in their cartography of pleasures, such as drinking rose rakia in Kazunluk, visiting the public house of Madame Klain in Belgrade and eating işkembe çorbası in Constantinople. ${ }^{29}$ This seems to be a clearer sign that tripe-soup consumption was becoming fashionable and that the trend originated in Constantinople.

In her description of Sofia at the beginning of the twentieth century, Rayna Kostentseva mentioned tripe soup as part of home cooking. ${ }^{30}$ Indeed, the first two cookbooks by Bulgarian authors - Petko Slaveykov (1870) and Dmitriy Smrikarov (1874) $)^{31}$ - did not contain any recipes for tripe soup, but two others which closely followed them did. Both Anton Delev, who authored the first published instructions for cooking tripe soup in Bulgarian, and the anonymous author of an 1895 cookbook advised the domestic cook how to clean and cut tripe, then seal it in a pot with dough and send it to be baked through the night in the public oven. Once the main ingredient was cooked, the tripe soup could be prepared. ${ }^{32}$

\footnotetext{
${ }^{26}$ VEZHINOV, P.: Izbrani suchinenia $v 4$ toma, p. 231.

${ }^{27}$ Ibid.

${ }^{28}$ SLAVEYKOV, P. R.: Gotvarska kniga ili nastavlenia za vsyakakvi gozbi spored kakto gi pravyat $v$ Tsarigrad.

${ }^{29}$ KARAVELOV, L.: Mamino detentse.

${ }^{30}$ KOSTENTSEVA, R.: Moyat roden grad Sofia.

${ }^{31}$ SLAVEYKOV, P. R.: Gotvarska kniga ili nastavlenia za vsyakakvi gozbi spored kakto gi pravyat $v$ Tsarigrad; SMRIKAROV, D.: Dodatutsi ba Zlatnia izvor.

${ }^{32}$ DELEV, A. N.: Semeyno sukrovishte, p. 461; N. A.: Domashna gotvarska kniga, p. 23.
} 
During this period, two manuals for girls' schools were released, both instructing them that the belly can be roasted on the grill or boiled with vegetables. ${ }^{33}$ Among the remaining cookbooks published before 1907 only Hristina Yurdanova's (1903) offered a recipe for tripe, which is entirely cooked at home as a soup or a stew. ${ }^{34}$

It seems reasonable to conclude that, by the turn of the twentieth century, the consumption of tripe soup in restaurants was associated with Ottoman urban culture and that the domestic cook was fairly familiar with it too. Tripe seems to have been considered of lesser quality than other by-products like the heart, head and liver, yet its consumption was not unusual. It is possible that shkembedzhiynitsi, the Turkish urban model of eateries, spread in Bulgarian cities only sometime after 1912-1915.

In any case, it is clear that Constantinople had a deep influence on Bulgarian foodways. Despite Bulgaria gaining independence from the Ottoman Empire in 1878, Constantinople's foodways were borrowed and shkembedzhiynitsi, which were quite literally copied from the Turkish işkembe salonu, were omnipresent in Sofia by the interwar period. These were simple places where customers would stay only as long as was needed for them to slurp down their hot and spicy soups. A counter divided the dining space from the kitchen in the back, where there were large cauldrons. There, a cook chopped up boiled tripe: roughly or finely, in single or double servings. He then tossed the pieces into a metal bowl, poured in steaming mixture of meat bouillon and milk from the cauldron and handed the dish to the customer. Spicy red pepper and a condiment made of garlic and vinegar were usually sprinkled on top. People paid at the exit. The only difference with Constantinople/Istanbul, at least in the late communist period, was that on leaving they were not offered cloves to freshen their breath. ${ }^{35}$

The writer Dragan Tenev recalls that in the 1930s that godini were considered "trendy" places, regularly visited by upper-class bohemians. The most popular shkembedzhiynitsa, Damarche, "opened as early as at four a.m. and was often visited at this hour by ladies in long gowns and men in tailcoats and tuxedos, who thought it was supremely chic to gulp down a bowl of shkembe after a ball". ${ }^{36}$

Cookbooks from the period did not discriminate against tripe soup, either. While admitting that it was cheap, even the most sophisticated and cosmopolitan

${ }^{33}$ APOSTOLOV, D. P.: Rukovodstvo po domakinstvo za devicheskite uchilishta, p. 183; KASEVA, K. I.: Uchebnik po domakinstvo: Za 6 klas na devicheskite gimnazii, p. 90.

${ }^{34}$ YURDANOVA, H.: Rukovodstvo po gotvarstvo, potrebno za vsyako semeystvo, p. 15.

${ }^{35}$ ZAHARI, N. A.: Shkembedzhiynitsite [The shkembedzhiynitsi]. In: Sofia predi 50 godini [Sofia 50 years ago] [online]. [Accessed 2021-11-16.] Available from: http://sofia50.blogspot. com/2008/01/23.html.

${ }^{36}$ TENEV, D.: Trista-hilyadna Sofia i az mezhdu voynite, pp. 285-289. 
cookbooks featured a recipe for it (e.g., Kassurova and Dimchevska's from 1933). ${ }^{37}$ As Anna Hakanova wrote in her Bulgarian National Dishes (1937), "[tripe] soup is a fortunate combination of taste, nutritiousness and cheapness! It won't be an overstatement to say that, in our hard times, many eat enough only thanks to this soup." Writing about its method of cooking, Hakanova indicated that cooking tripe in a restaurant is easier, as at home it would be difficult to maintain a hot stove for the many hours needed for the tripe to slowly cook. Therefore, just like her predecessors, she sent the housewife to take her pot, sealed with dough, to the public oven. ${ }^{38}$

The public ovens, which were widespread in Bulgarian cities before 1948, gradually disappeared when the communist regime took the economy into its hands and obliterated private businesses. In the communist state between 1948 and 1989, shkembedzhiynitsi fell under the jurisdiction of the centralized government, which tried to channel restaurants into manageable uniformity. The Cook's Manual from 1959 specified that "chairs and tables must be of the same sort. Tables need to be covered with hard covers, such as decorative linoleum, marble, oilcloth or glass." The book suggested that some tripe-soup places were serviced by waiters but insisted that all of them should introduce self-service. ${ }^{39}$

The new political management had an ambivalent attitude towards tripe soup and shkembedzhiynitsi. While striving to build a culture which would come across as modern and non-Oriental, it had very simple tastes in food. Thus, shkembe remained on the menu of many of the representatives of the new establishments, often as an after-party food. ${ }^{40}$

On the other hand, due to the approach of urban planners, it transpired that shkembedzhiynitsi were not particularly valued. In many cities, the communist authorities developed ambitious plans to adapt urban centres to communist modernity. Old neighbourhoods were destroyed to make way for new public buildings, and commercial zones were restructured to reflect the interests of the nonmarket economy. ${ }^{41}$ The process did not target shkembedzhiynitsi specifically, yet it marginalized them: those with central locations closed and only those towards the outskirts of the cities survived. The state statisticians did not keep track of tripe-soup joints separately, but in the 1970s they did include an account of the

\footnotetext{
${ }^{37}$ KASUROVA, B. - DIMCHEVSKA, S.: Gotvarska kniga: $S$ polezni uputvania za mladata domakinya.

${ }^{38}$ HAKANOVA, A.: Bulgarski narodni gozbi, p. 12.

${ }^{39}$ ALEXANDROV, M. (ed.): Naruchnik na gotvacha, pp. 48-51.

${ }^{40}$ SHKODROVA, Albena: Soc Gourmet [Soc(ialist) Gourmet]. Plovdiv, Zhanet 452014 , pp. 245-251.
}

${ }^{41}$ Ibid., pp. 99-100. 
dining places, including shkembedzhiynitsi: their numbers dropped by a quarter between 1970 and 1978 - from 1,952 to $552 .{ }^{42}$ A strategic economic research report showed that by 1975 there were in total twelve shkembedzhiynitsi in the country - fewer than the seventeen restaurants housed in train carriages. ${ }^{43}$

One important feature of shkembedzhiynitsi were their low prices. Many accounts suggest that they attracted two types of people: workers and political pariahs. The latter sometimes literally survived on shkembe chorba. Dissident writer Georgi Markov wrote of a friend who, for political reasons, was forced to eke out an existence with no financial means and who found salvation in cheap and nutritious tripe soup, which he ate three times a day for two months in a row. ${ }^{44}$ Such cases became quickly known to the small society of Sofia, adding charm to shkembedzhiynitsi in the eyes of the intellectual elite, many representatives of which were pampered by the system and yet despised its oppressiveness and provincialism. Painters, writers and other intellectuals recall the tripe-soup joints as alternative places of freedom..$^{45}$ All this led to a certain romantic, rebellious aura surrounding the shkembedzhiynitsi.

It seems that tripe was also mainly eaten in shkembedzhiynitsi under communism because its procurement was problematic. People recall that it was sold only occasionally, in a few places, and was accessible through queues or connections. Journalist Evgeniy Todorov, in his blog on everyday life in communist Plovdiv, recalled that even shkembedzhiynitsi hardly had enough tripe to operate.

Another important structural change which transpires in the cookbooks of late socialism is that sometime in the 1980s, at least in theory, semi-prepared tripe was available for sale in shops. ${ }^{46}$ The main ingredient for tripe soup was certainly delivered to the shops in a processed form after the fall of communism,

${ }^{42}$ Statisticheski godishnik na NRB [Yearly Statistic Book of People's Republic of Bulgaria]. Sofia, Durzhavno Izdatelstvo 1979, p. 330.

${ }^{43}$ KARANFILOV, Spas - PORTNIH, Nikolay: [Report on] Main Directions of Consumer Trade and Restaurants Development. The report is kept in: Tsentralen durzhaven archiv [The Central State Archives], Sofia, Reports, Vol. 707, No. 3-3 (1976), p. 103.

${ }^{44}$ MARKOV, Georgi: Zadochni reportazhi za Bulgaria [In Absentia Reports about Bulgaria], Vol. 1. Sofia, Ciela 2008, p. 342.

${ }^{45}$ BERN, Maxim: Shkembedzhiynitsa vduhnovyava poeti s aprilski surtsa [Shkembedzhiynitsa Inspired Poets with April Hearts]. In: Frog News [online], 20. 7. 2011. [Accessed 2021-11-16.] Available from: https://frognews.bg/laif-stail/hrana-vino/shkembedjiinitsa-vdahnoviava-poetite-aprilski-sartsa.html; KRUSTEVA, Elena: Hudozhnikut Nikola Manev: Purvo kone vidyaha nay-dobrite mi kartini [Painter Nikola Manev: It Was Horses Who First Saw My Paintings.] In: Blog.bg [online], 14. 06. 2008. [Accessed 2021-11-16.] Available from: http://elenak.blog.bg/ zabavlenie/2008/06/14/hudojnikyt-nikola-manev-pyrvo-kone-vidiaha-nai-dobrite-mi-ka.202368.

${ }^{46}$ SARALIEV, P.: Gotvarska kniga za muzhe, p. 39. 
when the significant import of industrially cleaned tripe from the United States began, starting in 1994. The free market gradually provided a steady supply of cooked tripe: frozen or vacuum-sealed, of local or foreign origin, and it is now widely available in grocery stores.

Another change in its importance, which also started in late communism and rapidly evolved after 1989, was that shkembe chorba went beyond the limits of shkembedzhiynitsi and was sold in many other types of restaurants as well. It was on the menu at decorative ethnic-style mechani, which the regime had created to attract foreign tourists with claimed authenticity and was even featured in chic locations like the Sheraton Hotel Balkan. Private restaurants proliferated after 1989, and many started adding tripe soup to their menus, transforming it into a mainstream dish, further marginalizing shkembedzhiynitsi.

Almost every cookbook continued to feature the generic recipe for tripe soup through the communist decades in a similar way to the period before 1948. Towards the 1980s dishes, involving tripe, started expanding in variation and their internationalization - some cookbooks included recipes from Germany, Poland and Italy. ${ }^{47}$

A number of stereotypes were coined around tripe soup during these historical developments and the next section of the article outlines several of them, which seem the most relevant to this research. The effect of each of them on the "gendering" of the dish is discussed later in the article.

Discourses on the Qualities and Consumption of Tripe Soup and Their Historical Roots

\section{Non-domestic Food Tied to Professional Kitchens and Public Eateries}

The source material prior to 1948 connects tripe soup with both professional and domestic kitchens. The early cookbooks suggest that it was being cooked in Bulgarian urban households by the beginning of the twentieth century based on a variety of recipes. But at least since the 1930s, shkembedzhiynitsi spread within the urban centres, attracting both poor and rich. ${ }^{48}$ These eateries are most likely responsible for unifying tripe-soup preparation according to the recipe popular in Istanbul. In Ivanov's cookbook from 1937, the recipe calls for tripe, milk and a crushed-garlic-vinegar-hot pepper concoction, which is described as

\footnotetext{
${ }^{47}$ SMOLNICKA, S.: Izkustvoto da gotvim; IDEM: Supi i sosove.

${ }^{48}$ TENEV, D.: Trista-hilyadna Sofia i az mezhdu voynite.
} 
Istanbulian. ${ }^{49}$ For over a century, this recipe has remained the gold standard or the generic recipe for what tripe soup is considered to be in Bulgaria.

But it is reasonable to state that in the following decades tripe soup was to certain extent "undomesticated". The aforementioned instructions in Hakanova's book offer a clue as to how and when the process must have begun. She wrote that it is easier for a restaurant to guarantee the prolonged cooking of the dish, while domestic cooks should use public ovens. ${ }^{50}$ These ovens must have disappeared in the late 1940s and early 1950s, when all private initiatives were as good as banned by the communist state. They are not mentioned in the cookbooks published after 1948. The disappearance of the public ovens was only one of the several structural conditions, that discouraged the practice of cooking tripe soup in the household during communism.

During most of the communist period, offal was sold uncleaned, which meant that the preparation of shkembe chorba involved the laborious scrubbing of tripe with industrial lime. While such labour-intensive cooking may have been commonplace prior to the Second World War, the communist state employed most women of active working age in the state economy, and thus sharply reduced their time in the household, enforcing significant changes in cooking patterns. ${ }^{51}$ The long cooking hours were also problematic at home due to the lack of technology: electric stoves were only widely introduced to urban households in Bulgaria in the late 1970 s. $^{52}$

These circumstances combined with the emerging arbitrage economy of permanent shortages, ${ }^{53}$ which made tripe one of the many products that were difficult to procure. Within the communist supply system, restaurants often found themselves in a privileged position relative to the general consumer. Thus, tripe soup was more associated with professional kitchens than with domestic ones by the 1970s and 1980s. The available accounts from this period almost exclusively

\footnotetext{
${ }^{49}$ IVANOV, V.: Gotvarska kniga specialno za gotvachi i domakini, p. 97.

${ }^{50}$ HAKANOVA, A.: Bulgarski narodni gozbi, p. 12.

${ }^{51}$ SHKODROVA, Albena: Rebellious Cooks and Recipe Writing in Communist Bulgaria. London - New York, Bloomsbury 2021, p. 24.
}

${ }^{52}$ DINKOVA, Maria: Socialniat progres na bulgarskata zhena [The Social Progress of the Bulgarian Woman]. Sofia, Sofia-Press 1972, p. 85.

${ }^{53}$ HRISTOV, Todor: Shortage Economy / Arbitrage Economy. In: Sociologicheski problemi [Sociological Problems], Vol. 47, No. 1-2 (2015), pp. 92-110; DEYANOV, Deyan: Society of Networks and Socioanalysis of the Gift (Pierre Bourdieu and Ivo Mozny). In: Ibid., Vol. 35, No. 1-2 (2003), pp. 72-86; BUNDZHULOV, Andrey: What Comes in the Place of? "Artificial Joints" and Networks under Socialism. In: Ibid., pp. 87-105; NIKOLOVA, Nina: Private Space under Socialism? In: Ibid., Vol. 43, No. 3-4 (2011), pp. 148-164. 
refer to the consumption of tripe soup in shkembedzhiynitsi. ${ }^{54}$ While it was cooked in some households, there is evidence that this was not very common. My previous research on domestic cooking scrapbooks of late communist times has established that the recipe for tripe soup was not part of the body of widely shared recipes, ${ }^{55}$ and personal experience as well as a short survey among my social network support this argument.

Finally, contemporary sources suggest a rapid re-domestication of tripe soup in the 1990s, when processed tripe was offered in the shops. From a dirty, stinky and laborious chore, the home cooking of tripe soup became possible "in 5 minutes". ${ }^{56}$ The 2010s in particular saw an expansion of publications where tripe was portrayed as an easy-to-cook domestic dish.

The shift over time in the degree to which the dish was associated with domestic cuisine and domesticity, must be relevant to its gendering - the linking of cooking and consuming foods "outside" with "masculinity" as opposed to "inside" with "femininity" is well illustrated by perceptions about coffee in Italy, ${ }^{57}$ hummus in Israel ${ }^{58}$ and hard alcohol in Spain. ${ }^{59}$ Some elements of this pattern of association are also visible regarding tripe soup in Bulgaria. The earliest sources associate its restaurant consumption with men and retrospective accounts of the communist period portray it as a manly pleasure, while its re-domestication in the 1990s resulted in the multiplication of female claims to it. But there are also inconsistencies - one example is the aforementioned eager consumption of tripe soup by women in the small hours of the morning in Sofia in the 1930s - which are discussed further below in this article.

\footnotetext{
${ }^{54}$ MARKOV, G.: Zadochni reportazhi za Bulgaria, p. 342; TODOROV, Evgeniy: Filii, banichki i chorbi [Bread Slices, Filo Pastry and Soups]. In: Blog.bg [online], 29. 08. 2009. [Accessed 202111-16.] Available from: https://zaprehoda.blog.bg/biznes/2009/08/01/filii-banichki-i-chorbi.3 72877?reply=1359958\&fbclid=IwAR2apgxzwjEbBT1-ZVKKoufJUpAEKcqF0v-16cub1ElCFwSPZXMal3Atr8; ZAHARI, N. A.: Shkembedzhiynitsite [online].

${ }^{55}$ SHKODROVA, A.: Rebellious Cooks.

${ }^{56}$ [Anonymous:] Shkembe chorba za 5 minuti [Shkembe chorba in 5 minutes]. In: Vkusi.me [online], undated. [Accessed 2021-11-16.] Available from: https://www.vkusi.me/raziadki/ shkembe-chorba-za-5-minuti-ot-gotvachkovcite/.

${ }^{57}$ REITZ, J. K.: Espresso: A Shot of Masculinity.

${ }^{58}$ HIRSCH, D.: Hummus Masculinity in Israel.

${ }^{59}$ DRIESSEN, Henk: Drinking on Masculinity. In: GEFOU-MADIANOU, Dimitra (ed.): Alcohol, Gender, and Culture. New York, Routledge 1992, pp. 71-79.
} 


\section{Inelegant Food, Repulsive to Many}

Tripe is a controversial foodstuff in most European cultures - the American psychologist Paul Rozin spoke of "the trauma of tripe"..$^{60}$ In Bulgaria, tripe soup is deemed strongly inelegant. Spicy, hot and garlicky, it involves slurping, causes a runny nose and makes one's breath smell of garlic for some time.

Slurping is permanently attached to the idea of tripe soup consumption. This is evident from contemporary publications, which regularly describe celebrities from various domains of culture and sport being "caught" as if in some transgression: "Galena slurps tripe soup with yogurt";61 "Berbo slurps tripe soup in the heart of Sofia"; ${ }^{62}$ "Slavi slurps tripe soup". ${ }^{63}$ The spiciness is also related - in the imagination and in reality - to the secretion of bodily fluids like sweat and mucous.

The texture of tripe soup is considered problematic, too. One popular joke from the 1970s compares it to a rag: "A customer stands before the cauldron with soup and waits for the cook to cut his meat. They chat, but suddenly the client notices that the cook has absentmindedly started chopping the kitchen towel. 'Yo, chef, why are you mincing this rag?' Startled, the cook looks at his hands and quickly shouts back: 'What? Do you want me to mince you a Persian carpet for 20 stotinki?'”

These qualities of tripe soup have fused certain hygienic issues into the popular discourse. Noting the resemblance of tripe to terrycloth, humorous folklore also claims that it is tastiest when not entirely cleaned before cooking. The idea that a bit of dirt is what makes the taste great is recurrent in tripe-soup narratives. Some involve a sultan, others the Bulgarian monarch or prime minister; but the plot remains the same. Hoping to learn the secret of a particularly good tripe soup, the sovereign relates the practice of his own chef to a knowledgeable cook. When he reaches the moment of scrubbing, the cook exclaims: "Stop! Here is the mistake! Never wash the tripe too well!" Even if this claim is not entirely serious, it found its way into restaurant reviews on the Internet. One guide

\footnotetext{
${ }^{60}$ ROZIN, Paul: Eating Ambivalence and Fear of Food: Shakespeare and Rozin. In: Creative Tastebuds Symposium [online], 31. 08. 2018. [Accessed 2021-11-15.] Available from: https:// www.youtube.com/watch?v=2PCEvo_vL_I.

${ }^{61}$ [Anonymous:] Galena surba shkembe chorba s kiselo mlyako. In: Pik.bg [online], 30. 01. 2018. [Accessed 2021-11-15.] Available from: https://pik.bg.

62 [Anonymous:] Berbo surba shkembe chorba na pupa na Sofia. In: Retro.bg [online], 23. 09. 2019. [Accessed 2021-11-15.] Available from: https://retro.bg.

${ }^{63}$ [Anonymous:] Slavi surba shkembe chorba. In: Stars.bg [online], 19. 05. 2010. [Accessed 2021-11-15.] Avalaible from: http://www.stars.bg.
} 
to shkembedzhiynitsi comments that the tripe soup at Hassan's place is so good because it is "slightly greasy and not too clean". ${ }^{64}$

Researchers have established the firm correlation of roughness with masculinity across cultures, just as elegance is associated with femininity. Thus, foods eaten in what is considered to be an inelegant way are often perceived as "masculine", in opposition to "femininity". One such example was put forward by Hirsch, who found that the inelegant manner of eating hummus - using broad movements with your hands to wipe it from the plate with a piece of pita bread - pushed women to abstain from its consumption in public places. ${ }^{65}$ Some of the evident discourse regarding tripe soup in Bulgaria reveals a similarly stable compound between roughness and masculinity, or rather its negative version, namely that a lack of elegance is incompatible with femininity. "Every gal could eat a banana erotically but try slurping down tripe soup in a sexy way!" reads a joke from one of the popular websites for vicove. ${ }^{66}$

Tripe soup unites seemingly incompatible opposites: the delicious and the inedible, the attractive and the averse. The discourses construct it as a "borderline" food - one on the verge of the social convention of "propriety". And this, in turn, leads to another discourse on the dish: that it is a food for the brave and adventurous.

\section{Adventurous Food for the Daring}

In a striking way, each aspect of the popular discourse on tripe soup seems to merge with the rest, reinforcing them and creating a solid, consistent idea which is able to regenerate itself when encountering the nuances of individual experiences. The potential aversion associated with tripe soup increases the perception of its consumption as challenging the social conventions. This challenge is seen as an adventure. Tripe soup itself appears to create borders: either loved or hated, it leaves no one indifferent. ${ }^{67}$

\footnotetext{
${ }^{64}$ [Anonymous:] Taynite mesta za shkembe chorba v Plovdiv [The Secret Spots to Eat Tripe Soup in Plovdiv]. In: Lost in Plovdiv [online], undated. [Accessed 2021-11-15.] Available from: http://www.lostinplovdiv.com/bg/articles/тайните-места-за-шкембе-чорба-в-пловдив.

${ }^{65}$ HIRSCH, D.: Hummus Masculinity in Israel.

${ }^{66}$ Vicove is the Bulgarian word for short popular jokes, which proliferated particularly under communism. [Anonymous:] Vsyaka kifla mozhe da yade banichka erotichno [Every Chick Can Eat Banitsa Erotically]. In: Vicove.biz [online], undated. [Accessed 2021-11-15.] Available from: http://www.vicove.biz/4aaa95451a1694321d09a47d08221bdc.
}

${ }^{67}$ KYOSEV, Hristo: Putevoditel na nay-dobrata shkembe chorba v Bulgaria: Vuzhvala na ambroziata [Guide to the Best Tripe Soup in Bulgaria: A Song to the Ambrosia]. In: Frog News [online], 29. 07. 2011. [Accessed 2021-11-16.] Available from: http://frognews.bg/kultura/art-jungla/ patevoditel-nai-dobrata-shkembe-chorba-balgariia.html.; [Anonymous:] Shkembe chorba 
The feeling of adventure is enhanced by structural circumstances, like the gradual removal of shkembedzhiynitsi out of city centres towards the outskirts and along big national roads. Four recent guides to the best tripe-soup joints illustrate the cultural significance of this particular circumstance. The selection and descriptions demonstrate the authors' inclination to present tripe-soup eating as an adventurous, rough experience. Train and bus stations, factories and highways are often cited to indicate the places' whereabouts. Instead of quoting the address, these publications point at the proximity to locations such as graveyards, public lavatories, petrol stations, ports, train stations, police stations or "Roma neighbourhoods".68

Furthermore, the interwoven aspects transform this perception of bordercrossing adventurousness into a way to cross lines of social division. "[Shkembe chorba] is eaten with equal gusto by bankers and deputies, by teachers and writers, by drivers and workers," wrote Hristo Kyosev. ${ }^{69}$ Nikolay Ilchevski similarly stated: "I know a pack of lawyers, bankers, accountants, policemen, musicians, administrators and other people with independent professions who search the town, rush from one place with shkembe on the menu to the other and trade discoveries like spies in enemy territory." ${ }^{70}$

A certain freedom-related perception can be seen in this description, a kind of liberation achieved through the very act of visiting a shkembedzhiynitsa or consuming tripe soup. The roots of such views can be identified in the earlier communist cultural framework - then, due to the marginalization of both shkembedzhiynitsi and their visitors, these eateries were seen as colourful, slightly dangerous and serving as a getaway from the oppressively normative communist society. To intellectuals, the lure of political trespassing was added to the charms of social transgression. The latter seems to be quite similar to the "persistent cross-cultural story of the streets' seduction among denizens of bourgeois parlours", which Krishnendu Ray observed in relation to street food consumption in India. ${ }^{71}$

[Tripe Soup]. In: Gozbata [online], 25. 10. 2017. [Accessed 2021-11-16.] Available from: http:// www.gozbata.com/шкембе-чорба/.

${ }^{68}$ KYOSEV, H.: Putevoditel na nay-dobrata shkembe chorba v Bulgaria [online]; [Anonymous:] Na tezi mesta shte hapnete nay-dobroto shkembe v Bulgaria [In These Places You Will Find the Best Tripe in Bulgaria]. In: Little BG [online], undated. [Accessed 2021-11-16.] Available from: https://littlebg.com/na-tezi-mesta-shte-hapnete-nai-dobroto-shkembe-v-bg/.

${ }^{69}$ KYOSEV, H.: Putevoditel na nay-dobrata shkembe chorba v Bulgaria [online].

${ }^{70}$ ILCHEVSKI, N.: Iznevyara na petia etazh.

${ }^{71}$ RAY, Krishnendu: Street-food, Class, and Memories of Masculinity: An Exploratory Essay in Three Acts. In: Food, Culture \& Society, Vol. 21, No. 1 (2018), pp. 89-100. 


\section{A Cure after Excessive Drinking}

Another way in which tripe soup serves to transgress borders is its association with excessive alcohol consumption. As old and contemporary sources alike suggest, Bulgarians consider it an excellent cure for hangovers. Some rate it amongst the top three remedies for recovery after heavy drinking, together with homemade fermented cabbage juice and ayran..$^{72}$ One blogger even calls it "the brother of beer" ${ }^{73}$ Hard alcohol and excessive drinking are often associated with manliness. As the Dutch anthropologist Henk Driessen claimed, "it is considered masculine to get drunk once in a while". ${ }^{74}$

\section{Discussion}

How Was Shkembe Chorba Entangled with Notions of Masculinity and Femininity?

Thus far, it seems clear that tripe soup has a good potential to symbolize what Roland Barthes calls the "primitive force of nature".$^{75}$ Its associations with meat, inelegance, excess, adventurousness and transgression, along with its love-it-orhate-it quality, form a strong cluster of symbols attached to masculinity across cultural borders. ${ }^{76}$

But how did this association become constructed and how did it evolve? Sources from the period before the Second World War are sketchy, but some signs of tripe soup's association with masculinity can be seen in writings as early as that of Lyuben Karavelov. ${ }^{77}$ There, the pursuers of tripe-soup pleasures were clearly men, since they also frequented a public house in Belgrade. The aforementioned recollection of Pavel Vezhinov from the 1920s involved boys who, after playing wildly in the street, took tripe home for their mothers to cook. ${ }^{78}$

\footnotetext{
${ }^{72}$ [Anonymous:] Na tezi mesta shte hapnete nay-dobroto shkembe v Bulgaria [online].

${ }^{73}$ YANEVA, Marina: Shkembe chorba za vsyaka zhena [Tripe Soup for All Women]. In: Jenite.bg [online], 30. 09. 2012. [Accessed 2021-11-16.] Available from: http:/Jenite.bg/шкембе-чорба-за-всяка-жена_l.a_i.224960.html.

${ }^{74}$ DRIESSEN, H.: Drinking on masculinity, p. 79.

${ }^{75}$ BARTHES, Roland: Vuobrazhenieto na znaka [The Imagination of the Sign]. Sofia, Narodna kultura 1991, p. 113.

${ }^{76}$ LUEPTOW, L. B - GAROVICH, L. - LUEPTOW, M. B.: The Persistence of Gender Stereotypes in the Face of Changing Sex Roles, p. 513.

${ }^{77}$ KARAVELOV, L.: Mamino detentse.

${ }^{78}$ VEZHINOV, P.: Izbrani suchinenia $v 4$ toma, Vol. 3, p. 231.
} 
The female sources - for example Kostentseva's and Hakanova's books ${ }^{79}$ - do not suggest gendering, but neither do they exclude it. Dragan Tenev though explicitly mentions the participation of men and women in post-festive feasts featuring tripe soup in Sofia during the 1930s in equal measure. ${ }^{80}$

The communist regime brought important structural changes. The radical social rearrangement eradicated the upper classes and their lifestyle and caused rapid urbanization. Between 1946 and 1995, the country's urban population grew from 24.7 to 64.8 percent. ${ }^{81}$ The customers of the shkembedzhiynitsi changed: the swelling working class replaced the upper-class bohemians, at least until a new upper-middle class was formed within the new state in the 1960s.

Regardless of the well-known criticism towards the communist "liberation" of women, it is a fact that throughout the 1950s the regime employed most of the active female population and aimed at obliterating the "gendering" of different types of work. As Georgi Markov noted, it often even tried to ignore the physiological differences between the sexes. ${ }^{82}$ Notably, both the new working class and the intelligentsia of the communist state were comprised of just as many men as women.

Yet some sources suggest that shkembedzhiynitsi and their tripe soup were the privilege of men. In his retrospective recollections of the communist period, Evgeniy Todorov, for example, reiterates this three times. ${ }^{83}$ The comments under the online publication of his 2009 work share the exclusive experiences of men in the cities of Plovdiv and Sofia under communism. In another popular blog on communist everyday life, Sofia predi 50 godini [Sofia 50 years ago], the author explicitly identifies the experience as "masculine". ${ }^{84}$ The retrospective character of these accounts leaves open the possibility that contemporary perspectives have affected the interpretation of memories, but the degree of uniformity suggests the opposite.

Women's accounts are less vocal. Still, they suggest that the situation was less straightforward. In Bulgaria, an entire generation was raised with the idea that eating tripe soup in shkembedzhiynitsi is something adventurous and cool, and the online publications analysed present evidence of this. In one of them the journalist and writer Milena Fuchedzhieva transports her experience from Sofia

\footnotetext{
${ }^{79}$ KOSTENTSEVA, R.: Moyat roden grad Sofia; HAKANOVA, A.: Bulgarski narodni gozbi.

80 TENEV, D.: Trista-hilyadna Sofia i az mezhdu voynite.

${ }^{81}$ Statisticheski godishnik na NRB [Yearly Statistic Book of People's Republic of Bulgaria]. Sofia, Durzhavno Izdatelstvo 1993, p. 47.

${ }^{82}$ MARKOV, G.: Zadochni reportazhi za Bulgaria, p. 260.

${ }^{83}$ TODOROV, E.: Filii, banichki i chorbi [online].

${ }^{84}$ ZAHARI, N. A.: Shkembedzhiynitsite [online].
} 
in the 1980s to contemporary Los Angeles: "I recalled that in the Mexican market in downtown LA, a joint prepared delicious menudo - i.e. tripe soup. With no delay, I called my friends with whom I'd partied the previous night, and we rushed towards the tripe. ${ }^{\prime 85}$

In this narrative, several symbols that are strongly associated with masculinity - eating tripe soup and, implicitly, excess drinking of alcohol and partying are brought together. Scholars have argued that foods strongly associated with one gender are often used to signal gender identity ${ }^{86}$ They can therefore also be used to defy gender borders - or the borders of "propriety" in general.

Contemporary sources are the most abundant and allow for the best insights into how this gendering occurred and is contested. In the post-communist liminality after 1989, the social pressure for women to be employed ceased. However, inertia, economic pressure and other factors preserved the parity between men and women in the labour market. ${ }^{87}$ In this context, a clear contest over the gendering of shkembe chorba unfolded.

Today active gendering takes place and Ilchevski's words, quoted at the beginning of this article, summarize many aspects of it. Confining women to a castle of salads, stews and "other half-foods", suggesting that cooking and consuming tripe soup are male prerogatives, tying together references to adultery, boldness and inelegance, to the world outside as opposed to the domesticity of the home, many traits associated with masculinity are employed to consolidate the construct. ${ }^{88}$

Male expertise in the cooking of tripe soup is claimed. Culinary blogs by amateur male cooks remain exceptional in Bulgaria, and one of them features a video showing a father and his two sons preparing tripe soup. ${ }^{89}$ Tripe, speed and entertainment make for a combination of traits that has previously been observed to frequently "legitimize" men's involvement in the kitchen - by subtly reconstructing the familiar according to traditional societal hierarchies and power relations. ${ }^{90}$

${ }^{85}$ FUCHEDZHIEVA, Milena: Shkembe chorba v LA i pregrudki v Lyulin [Tripe Soup in LA and Hugs in Lyulin]. In: e-vestnik.bg [online], 12. 06. 2007. [Accessed 2021-11-17.] Available from: https://e-vestnik.bg/1366/шкембе-чорба-в-ел-ей.

${ }^{86}$ Amongst others: EKEBAS-TUREDI, C. et al.: A Cross-Cultural Analysis of Gender-Based Food Stereotypes; CAVAZZA, N. et al.: Ingredients of Gender-Based Stereotypes about Food; McPHAIL, D. et al.: "I Don't Want to be Sexist But...”; HIRSCHMAN, Elizabeth C. et al.: Exploring the Architecture of Contemporary American Foodways; LUPTON, D.: Food, the Body, and the Self.

${ }^{87}$ The World's Women 2015: Executive Summary. New York, United Nations 2015, p. 91.

${ }^{88}$ ILCHEVSKI, N.: Iznevyara na petia etazh.

${ }^{89}$ [Anonymous:] Shkembe chorba za 5 minuti [online].

${ }^{90}$ For example: GVION, Liora: Cooking, Food, and Masculinity: Palestinian Men in Israeli Society. In: Men and Masculinities, Vol. 14, No. 4 (2011), p. 408-429; JULIER, Alice - LINDENFELD, 
Other examples are recipes saturated with "mansplaining", where traits associated with masculinity are endorsed at the expense of others which might be interpreted as feminine: "I've been reading through recipes and I could no longer stand it. Tripe with yogurt and eggs. And with flour and other rubbish. First let's make clear when tripe soup is eaten in our lands. WHEN A CALF IS BEING SLAUGHTERED." So reads the introduction to a recipe by Angel Angelov. ${ }^{91}$ In the same strong language, he dismisses the domestication of tripe-soup cooking: if not in restaurants, it needs to take place in a cauldron and on a real wood fire. The length of cooking is measured in "one-cigarette" intervals of time, the salt comes in "handfuls", and the tripe is minced with a chopper on a beech block.

Further the exclusivity of the rituals is strengthened by their association with other male-dominated fields of public life, such as politics and football: "Shkembe fans argue over its preparation methods with the same passion with which politicians defend their self-stirred up mess. (...) Of shkembe-chefs, one speaks with such garlicky-peppery outflows as he would discuss football stars in the stadium." 92

Much of the media effortlessly perpetuate such discourses. Just one example, the online tabloid Hot Arena, described the habit of a pop music composer to secretly escape his home and wife in order to eat tripe soup in a nearby restaurant. ${ }^{93}$ Another consolidation of traits is found here, forming stable compounds with masculinity across cultures. The wife is depicted as getting cross with her husband's tripe-soup excess, while he is described as unpretentious (an undemanding attitude to food is often perceived as manly, according to Deborah Lupton). ${ }^{94}$

\section{(Some) Women Fight Back, but with Opposing Strategies}

Women, for their part, seem to be divided over the status of tripe soup. Some of them actively strengthen its stereotypical gendering, pronouncing it to be

Laura: Mapping Men On to the Menu: Masculinities and Food. In: Food and Foodways, Vol. 13, No. 1-2 (2005), pp. 1-16; LEER, Jonatan: What's Cooking, Man? Masculinity in European Cooking Shows after The Naked Chef. In: Feminist Review, Vol. 114, No. 1 (2016), p. 72-90.

${ }^{91}$ ANGELOV, Angel: Tsarska shkembe chorba [Tsar's Tripe Soup]. In: Sobstvenik Magazine [online], undated. [Accessed 2021-11-16.] Available from: http://www.sobstvenik.com/ tsarska-shkembe-chorba/.

92 ILCHEVSKI, N.: Iznevyara na petia etazh.

${ }_{93}$ [Anonymous:] Razvigor Popov tayno surba shkembe chorba [Razvigor Popov Slurps Secretly Tripe Soup]. In: Hot Arena [online], 30. 08. 2019. [Accessed 2021-11-16.] Available from: https://www.youtube.com/watch?v=68t5dByeS80.

${ }^{94}$ LUPTON, D.: Food, the Body, and the Self, p. 108. 
"the favourite dish of many men", ${ }^{95}$ while others generalize their own dislike for it as a gender attribute: "We, the ladies, do not particularly like this soup, we prefer chicken or potato cream soup, believe me. ${ }^{\prime 96}$ However, many women claim their equal rights on tripe soup. To this end, they notably undertake two distinctive strategies.

Some try to domesticate tripe soup or "demasculinize" it. One example is the attempt to disassociate it from the excessive consumption of alcohol: "I don't drink, but I adore tripe soup," a woman comments under a tripe soup recipe post, ${ }^{97}$ referring to the belief that tripe soup will cure a hangover. Another woman presents the dish as a family meal, explicitly mentioning that it is liked by her children, who "wouldn't eat the tripe itself, but very much like the rest". ${ }^{98}$ In an effort to lay claim to expertise in preparing tripe soup, Maria Stoyanova even declares it a duty for "every real lady". ${ }^{99}$

The second strategy, in contrast, tries to associate feminine identity with traits perceived to be traditionally masculine; this also seems to be the case regarding female discourses from the late communist period, like that of Milena Fuchedzhieva. ${ }^{100}$ One online post in this vein is challengingly titled "Tripe soup for all women". Its female author praises the "detoxing" and hangover-healing powers of shkembe chorba and makes a claim that the division runs not between the sexes but between the "cool" and the "uncool". ${ }^{101}$ This attitude is shared by other authors of publications, who ignore the issue of gender. Hristo Kyosev writes: "We should just note that the soul of a non-eater of tripe soup is dried and shrunken,

${ }^{95}$ STOYANOVA, Maria: Edna istinska dama tryabva da mozhe da prigotvya shkembe chorba! [A True Lady Must Know How To Cook Tripe soup!] In: Dama.bg [online], 21. 01. 2015. [Accessed 2021-11-15.] Available from: https://dama.bg/article/edna-istinska-damatriabva-da-mozhe-da-prigotvia-shkembe-chorba/4567/.

${ }^{96}$ Danaya Todorova's comment under the publication of YANEVA, Marina: Shkembe chorba za vsyaka zhena [Tripe Soup for All Women]. In: Jenite.bg [online], 30. 09. 2012. [Accessed 202111-15.] Available from: http:/Jenite.bg/шкембе-чорба-за-всяка-жена_l.a_i.224960.html.

${ }^{97}$ LUSSI, N. A.: Traditsionna Shkembe Chorba / Traditional Tripe soup. In: Lussi's World of Artcraft Blog [online], 02. 01. 2014. [Accessed 2021-11-17.] Available from: http://lussisworldofartcraft.blogspot.be/2014/01/blog-post.html.

${ }_{98}$ ANGELOVA, Petya: Lesna i burza shkembe chorba [Fast and Easy Tripe Soup]. In: Uhae na... [online], 30. 03. 2014. [Accessed 2021-05-17.] Available from: http://uhaena.blogspot.be/2014/03/ blog-post_30.html.

${ }^{99}$ STOYANOVA, M.: Edna istinska dama tryabva da mozhe da prigotvya shkembe chorba! [online].

${ }^{100}$ FUCHEDZHIEVA, M.: Shkembe chorba v LA i pregrudki v Lyulin [online].

${ }^{101}$ YANEVA, M.: Shkembe chorba za vsyaka zhena [online]. 
their virtuous pose of sobriety is a cover for some nameless and disgusting practice, I hope Steinbeck will forgive me [for borrowing his words]."102

There are also posts implicitly challenging the perception of the professional cooking of tripe soup as a man's privilege. One blogger claims that she herself has cooked tripe soup in a professional kitchen, having learned the method from another experienced female chef: "She always prepared shkembe for the staff, cooked in a giant cauldron" and "washed it just like dirty linen before cutting it into the pot". ${ }^{103}$ A female chef who prepares tripe soup might be considered an analogue of the "female butcher", whom Rosemary Pringle and Susan Collins argued to be a nearly impossible cultural category. ${ }^{104}$ In this particular publication, the non-problematized, naturalistic account of the facts seems to challenge the described stable compound between masculinity and dealing with animal flesh.

Previous research has shown that men tend to be more congruent with their masculine image as far as food consumption goes than women in different cultural frameworks. ${ }^{105}$ Elspeth Probyn and Dafna Hirsch argued that consuming food is never merely expressive of social identities; it participates in the construction of identity, a process in which people assume various roles. ${ }^{106}$ Likewise, Krishnendu Ray observed middle-class Indian women's consumption of paan and tobacco as a "marker of both female autonomy and of courtesan sensuality". ${ }^{107}$

Based on the available sources, it is difficult to judge whether those women who feel an untroubled love for tripe soup without trying to domesticate it are also trying to deconstruct the "stable compounds" between certain traits (adventurousness, love of excess, audacity) and masculinity or to inject a dose of masculinity into their female identities. These remain two different things which may, or may not, be two steps in the same process.

Considering the communist period, Biljana Raeva argued that, paradoxically, and despite its agenda to emancipate women, communism actively solidified

\footnotetext{
${ }^{102}$ KYOSEV, H.: Putevoditel na nay-dobrata shkembe chorba v Bulgaria [online].

${ }^{103}$ [Anonymous:] Shkemne chorba - klasika v kuhnyata [Tripe soup - A Classic in the Kitchen]. In: Domashni hitrini [online], 19. 01. 2015. [Accessed 2021-11-18.] Available from: https://hitrinibg.com/shkembe-chorba-klasika/.

${ }^{104}$ PRINGLE, Rosemary - COLLINS, Susan: Women and Butchery: Some Cultural Taboos. In: Australian Feminist Studies, Vol. 8, No. 17 (1993), pp. 29-45, here p. 30.

${ }^{105}$ EKEBAS-TUREDI, C. et al.: A Cross-Cultural Analysis of Gender-Based Food Stereotypes. ${ }^{106}$ PROBYN, Elspeth: Carnal Appetites: FoodSexIdentities. London, Routledge 2000; HIRSCH, D.: Hummus Masculinity in Israel, p. 339.

${ }^{107}$ RAY, K.: Street-Food, Class, and Memories of Masculinity, p. 96.
} 
traditional and even archaic ideas of masculinity. ${ }^{108}$ Men were projected as strong, aggressive, daring, independent, determined and invulnerable - qualities instrumental to state efforts at producing an army of dedicated workers. Indeed, the regime also expected the same from women. Although many ignored its ideology, they could not do the same with the arrangements of the communist state, which forced women to become breadwinners just like their husbands (but did not make their husbands equally responsible for the household). ${ }^{109}$

It is possible that the observed discourses reflect the controversial nature of women's emancipation - both under communism and today, ${ }^{110}$ with traditional values being reasserted and women pushed into a superficial understanding of gender equality that consists of the appropriation of some degree of masculinity, instead of deconstructing gendering. Further research, constructed to differentiate between appropriating masculinity and decomposing genders, needs to be done in order to answer these open questions.

The historical sources used for this research had their limitations, as they offered only partial insights into the reasoning of the "gendering" process. When does emancipation of women involve deconstruction of the stable compounds between traits and femininity/masculinity, and when does it reach appropriate masculinity? Where is the border between the two found in each society? Is the deconstruction of these stable compounds even possible? The theoretical model, offered here, will greatly benefit from further investigations, which will test it on the basis of more suitable, possibly sociological or anthropological sources.

\section{Conclusion}

This article suggests that it is useful to consider the process of food gendering as composed of several levels of codification. One of these is the perception of what constitutes masculinity and femininity in general and, as researchers have established, ${ }^{111}$ it is at its most conservative. The perception of traits as typical to

\footnotetext{
${ }^{108}$ RAEVA, Biljana: Geroizacia i muzhestvenost po vreme na socializma v Bulgaria prez 60 -te i 80-te g na 20 vek [Heroization and Masculinity in Bulgaria During Socialism]. In: Balkanistic Forum, Vol. 22, No. 3 (2013), pp. 152-163.

${ }^{109}$ SHKODROVA, A.: Rebellious Cooks, pp. 38-42.

${ }^{110}$ See for example PETROVA, Silvia - RUSKOVSKA, Rodna: Contemporary Woman between Feminism and Tradition. In: Identities: Journal for Politics, Gender and Culture, Vol. 7, No. 1-2 (2008), p. 201-231.

${ }^{111}$ WILLIAMS, J. E. - BEST, D. L.: Measuring Sex Stereotypes; LUEPTOW, L. B. et al.: The Persistence of Gender Stereotypes.
} 
one gender or another - for example, the association of masculinity with aggressiveness, risk-taking and excess, or femininity with sensitiveness and delicacy has not been observed to differ across varying cultural frameworks.

The second level of codification is the association of certain foods with a number of gender-specific traits, which are therefore attributed with the quality of "fitting" the respective gender. This level of codification does vary depending upon the cultural framework, either associating or disassociating certain foods with particular traits. For example, fish can be seen as an alcohol-related food in Turkey or a diet-related food in the United States, which seems to critically influence its perception as related to masculinity or femininity, respectively. ${ }^{112}$ The case study of tripe soup in Bulgaria shows how such fluctuations may occur over time and may be used, or even manipulated, in an attempt to control gender associations.

On this same level, however, a sort of stable compound tends to form, one which associates certain foods firmly with certain traits and therefore genders across cultures and periods. Examples of this are meat and alcohol, both associated with masculinity.

The third level of codification is the inclination of the sexes to transgress the borders set by the first two levels. As gender is not something that one is but something that one does, ${ }^{113}$ individuals assume their gender roles depending on circumstances, and it is possible that this level of "codification" is one of constant enactments, the most volatile of the three.

In regard to the emancipation of women, one can speculate that a critical mass of persistent transgressions on this third level might influence the other two levels of codification. In other words, if enough women would consistently enjoy excess, the perception of excess would become gender-neutral, and so would the perception of alcohol excess. But while the possibility seems open, there is no evidence that it has ever occurred. This case study suggests that even if such an "un-gendering" does happen for certain groups and over some periods of time, it is easily reversible.

The contribution of this article is in its attempt to systematize already discussed aspects of food gendering into a structured conceptual framework. This particular case study shows a very consistent model of gendering which has been consolidated or has lingered throughout these historical periods - a model that is particularly noticeable in contemporary discourses. The thus constructed

\footnotetext{
${ }^{112}$ EKEBAS-TUREDI, C. et al.: A Cross-Cultural Analysis of Gender-Based Food Stereotypes. ${ }^{113}$ WEST, Candance - ZIMMERMAN, Don H.: "Doing Gender." In: Gender \& Society, Vol. 1, No. 2 (1987), pp. 125-151.
} 
association of tripe soup with masculinity seems, however, to have been challenged by two different strategies. These differ in the levels of codification they address.

One contemporary strategy is changing the context, depriving it of elements which would relate a particular food with traits that are widely associated with masculinity. This strategy pushes to disassociate tripe soup from excessive drinking or adventurous experiences and to incorporate it into quiet familial routines, to associate it with children and domesticity.

The second strategy, which seems older, does not try to change the traits of this food but challenges the privilege of men alone to be associated with these traits. Fluctuations in the gender status of tripe soup seem to reflect shifts in the inclination of women to incorporate a degree of masculinity in their gender identity, rather than changes in the perceptions of what constitutes "the feminine" or "the masculine". Bulgarian women, those who gained emancipation between the two world wars and were raised in the communist ideological framework, seem to have minded being associated with masculinity less than those in postcommunist Bulgarian society, who have rejected the values of communism and face a new (and unhurried) discussion on the relationship between the sexes.

Appendix

Historical Bulgarian Cookbooks, Used as Sources for this Article

SLAVEYKOV, Petro R.: Gotvarska kniga ili nastavlenia za vsyakakvi gozbi spored kakto gi pravyat $v$ Tsarigrad [Cookbook, or Instructions on All Kinds of Dishes as They Are Cooked in Istanbul]. Tsarigrad, Pechatnitsa na Makedonia 1870; SMRIKAROV, Dmitriy: Dodatutsi ba Zlatnia izvor [Addition to the Golden Source]. Belgrade, Knigopechatnitsata na Nikola Stefanovic 1870; GREBENAROV, Mihail Yankov: Narodna pesnopoyka s gorvarska i lekarska nauka [People's Songbook with Cooking and Medical Science]. Sofia, Grebenarov 1889; DELEV, Anton N.: Semeyno sukrovishte [Family's Treasure]. Sofia, Pechatnitsa na "Liberalniy klub" 1891; Anonymous: Domashna gotvarska kniga [Domestic Cookbook]. Sofia, Bulgarski almanah 1895; IEGER, Marie: Prakticheski suvetnik po domakinstvo [Handbook in Householding]. Svishtov, D. I. T. 1899; APOSTOLOV, D. P.: Rukovodstvo po domakinstvo za devicheskite uchilishta [Household Manual for the Girls' Schools]. Plovdiv, D. V. Manchov 1900; STEFANOVA, Elisabet A.: Rukovodstvo po gotvarstvo (808 recepti) [Cookery Manual with 808 Recipes]. Sofia, Knizharnitsa Chipev 1904; KASEVA, Kina Iv.: Uchebnik po domakinstvo: Za 6 klas na devicheskite gimnazii 
[Household Textbook for Grade 6 of the Girls' Schools]. Sofia, Pechatnitsa Gavazov i Chomonev 1906; YURDANOVA, Hristina: Rukovodstvo po gotvarstvo, potrebno za vsyako semeystvo [Cooking Manual, Essential in Each Family]. Svishtov, D. T. Damyanov 1903; KASEVA, Kina Iv.: Uchebnik po domakinstvo: Za 4 i 5 klas na devicheskite gimnazii [Household Textbook for Grades 4 and 5 of the Girls' Schools]. Sofia, Pechatnitsa Gavazov i Chomonev 1903; KASEVA, Kina: Uchebnik po domakinstvo [Household Textbook]. Sofia, Slovo 1920; PEYKOVA, Teodora: Gotvarska kniga [A Cookbook]. Sofia, Iconomia i domakinstvo 1925; HAKANOVA, Ana: Novi Izpitani Retsepti [New Tested Recipes]. Sofia, Az-buka 1931; KASUROVA, Bogdana - DIMCHEVSKA, Spaska: Gotvarska kniga: $S$ polezni uputvania za mladata domakinya [Cookbook: With Useful Instructions for the Young Housewife]. Sofia, Pridvorna knizharnitsa Iv. B. Kasurov [1933]; HAKANOVA, Ana: Bulgarski narodni gozbi [Bulgarian People's Dishes]. Sofia, Vestnik za zhenata 1937; IVANOV, Vlado: Gotvarska kniga specialno za gotvachi i domakini [Cookbook Specially for Cooks and Housewives]. Sofia, Hudozhnik 1937; GEORGIEVA, Radka: Gotvarska kniga [Cookbook]. Sofia, Biblioteka Dobra Domakinya 1940; KRASTEVA, Ana: Malka gotvarska enciclopedia: Narodna kuhnya [Small Culinary Encyclopedia: People's Cuisine]. Sofia, Vuzhod 1940; CHORTANOVA, Sonya - NIKOLOVA, Pasha: Uchebnik po hrani i gotvarstvo za V klas $v$ devicheskite profesionalni zanayatchiyski uchilishta [Textbook on Food and Cookery for Grade 5 of the Girls' Professional Schools]. Sofia, no publisher 1942; MEDNIKAROVA, Maria: Gotvarska kniga, Vol. 2 [Cookbook, Vol. 2]. Sofia, Zemedelska knizhnina 1946; CHOLCHEVA, Penka: 1000 izpitani recepti za gotvene [1000 Tried and Tested Cooking Recipes]. Sofia, Knigoizdatelstvo Hristo Cholchev 1947; KAMBUROVA, Elena - STAVREV, Kiril - YANKOV, Todor: Gotveni yastia ot meso [Cooked Dishes with Meat]. Sofia, Profizdat 1953; NAYDENOV, Ivan - CHORTANOVA, Sonya: Nasha kuhnya [Our Cuisine]. Sofia, Meditsina i fizkultura 1955; CHOLCHEVA, P. - RUSEVA, Al. (eds.): Kniga za domakinyata [The Housewife's Book]. Sofia, Otechestven front 1956; SOTIROV, Natsko: Suvremenna kuhnya [Contemporary Cuisine]. Sofia, Tehnika 1959; SHISHKOV, Georgi - VUCHKOV, Stoil: Bulgarski nacionalni yastia [Bulgarian National Dishes]. Sofia, Profizdat 1959; ZAHARIEV, Zachary - VUCHKOV, Stoil - SHISHKOV, Georgi - BOYADZHIEV, Stefan: Sbornik gotvarski recepti za ZOH [Collection of Recipes for the Public Catering Units]. Sofia, Profizdat 1960; CHOLCHEVA, Penka - ANGELOVA, Vesa - KALENDEROVA, Maria et al.: Kniga za vseki den i vseki dom [A Book for Every Day and for Every Household]. Sofia, Technika 1967; MOSHLEV, Dimitur - POPOVA, Pavlina - BOZHILOV, Kiril - KARAIVANOV, Neno - PENCHEV, Panayot - POPOVA, Siyka: Retsepturnig po gotvarstvo i sladkarstvo [Cooking and Confectionary Recipes]. Sofia, Technika 1970; CHORTANOVA, Sonya - MARINOV, Marin: Yastia ot mesni polufabrikati i kolbasi [Dishes with Semi-Prepared and Cured Meat]. Sofia, Technika 1976; SMOLNICKA, Sofia: Izkustvoto da gotvim [The Art of Cooking]. Sofia, Technika 1980; ILIEVA, Nadezhda: Kulinaren spektur [A Culinary Spectrum]. Sofia, Zemizdat 1983; SARALIEV, Petur: Gotvarska kniga za muzhe [A Cookbook for 
Men]. Sofia, Zemizdat 1984; SMOLNICKA, Sofia: Supi i sosove [Soups and Sauces]. Sofia, Meditsina i fizkultura 1987; CHAUSHEV, Asen - CHAUSHEV, Nedko: Nova kuhnya [New Cuisine]. Sofia, Meditsina i fizkultura 1989.

\begin{abstract}
There is growing interest into how cultural frameworks produce stereotypes of "masculine" and "feminine" foods. The patterns and dynamics of this process have been discussed mainly from a socio-cultural perspective, but the research thus far has failed to create a conceptual framework to explain both the persistence in the association of some foods with a specific gender and shifts in others. Based on a case study of attitudes in communist and post-communist Bulgaria towards tripe-soup - a dish with great potential to be perceived as manly - this article suggests that it is useful to consider food gendering as composed of several levels of codification. One of them is the perception about what constitutes masculinity and femininity in general, and this transpires to be the most conservative and consistent across periods and cultural frameworks. The second level of codification is the attribution to foods of certain traits, which are then associated with the content of masculinity and/or femininity. The associations made on this level are sometimes able to shift, depending on the cultural framework, but they can also form stable compounds, such as the association between meat and masculinity. The third level of codification is the inclination of the sexes to transgress the borders set by the first two levels in the process of building their gender identity. As gender is not something that one is, but something that one does, individuals assume their gender roles depending upon circumstances, and it is possible that this level of "codification" is a level of constant enactments, the most volatile of the three. This article investigates how tripe soup was constructed as "masculine" and how these discourses have been challenged. It argues that the process reflects shifts in the acceptability of women's association with "masculinity", rather than changes in the perceptions of what constitutes "the feminine" or "the masculine".
\end{abstract}

Keywords:

Bulgaria; communism; post-communism; history of food; gastronomy; gender; food gendering; cookbooks; tripe soup 